\title{
The General Exemption of Section 522(d)(5) of the 1978 Bankruptcy Code
}

The Bankruptcy Reform Act of 1978 (the "Code")," as every commentator addressing it invariably notes, ${ }^{2}$ is the first major revision of bankruptcy law in over forty years. ${ }^{3}$ As befits so major an undertaking in so complex an area, the Code is lengthy, detailed, and-inevitably-flawed with technical error and ambiguity."

1 Pub. L. No. 95-598, 92 Stat. 2549 (1978) (codified as Title 11 of the United States Code (Supp. IV 1980)). The Code took effect on October 1, 1979, but its bankruptcy court system will not be fully implemented until April 1, 1984. See infra note 9.

2 The general commentary on the Code is too extensive for complete citation. For academic commentary, see, e.g., Aaron, The Bankruptcy Reform Act of 1978: The Full-Employment-for-Lawyers Bill (pt. 1), 1979 UтAн L. Rev. 1; Dole, The New Federal Bankruptcy Code: An Overview and Some Observations Concerning Debtors' Exemptions, 17 Hous. L. REv. 217 (1980); The Bankruptcy Reform Act of 1978, 28 EMORY L.J. 581 (1979). For commentary by judges and practitioners, see, e.g., Bare, The Bankruptcy Reform Act of 1978, 47 Tenn. L. Rev. 501 (1980); Chatz, Costello \& Gross, An Overview of The Bankruptcy Code, 84 Coм. L.J. 259 (1979); Hughes, Code Exemptions: Far-Reaching Achievement, 28 DePaur L. Rev. 1025 (1979); Lindsey, The New Bankruptcy Law: A Guide for the Non-Specialist, 54 CAL. ST. B.J. 368 (1979); Mapother, Federal Exemptions Under the Bankruptcy Code, 44 Ky. BENcH \& B. 12 (1980); Poorman, Bankruptcy Reform Act of 1978, 32 OкцA. L. Rev. 583 (1979); Williams, The New Bankruptcy Act - From a Creditor's Point of View, 6 Orange CounTY B.J. 15 (1979). For commentary by persons active in the enactment of the Code, see, e.g., Butler, A Congressman's Reflections on the Drafting of the Bankruptcy Code of 1978, 21 WM. \& MARY L. REv. 557 (1980); Klee, Legislative History of the New Bankruptcy Code, 54 AM. Bankr. L.J. 275 (1980). For treatises on the Code and its effect on bankruptcy practice, see, e.g., Collier on Bankruptcy (15th ed. 1979); Commerce Clearing House Editorial Staft, Bankruptcy Reporm Act of 1978 P.L. 95-598: Law, Explanation, Selected Commitree Reports (1978); D. Cowans, Bankruptcy Law and Practice (2d ed. Supp. 1979); Practicing Law Institute, Bankruptcy Rerorm Act of 1978 (1978).

s The Code repealed the Bankruptcy Act of 1898, Pub. L. No. 55-171, 30 Stat. 544, which had undergone its last major revision in 1938 under the provisions of the Chandler Act, Pub. L. No. 75-696, 52 Stat. 840 (1938).

- Congress has long been aware of the drafting shortcomings of the Code. Since March 14,1979 , at least three bills designed to correct technical errors in, clarify, and make minor substantive changes to the Code have been put before Congress and have passed in one or the other house, although none has yet passed in both. S. REP. No. 150, 97th Cong., 1st Sess. 1-2 (1981), reprinted in 1981 BANKR. L. REP. (CCH) No. 47, at 5-6 (extra ed.). The first of these bills was accompanied by a report noting that "[i]t is clear even at this early time in the life of this law that technical amendments are required." H.R. REP. No. 1195, 96th Cong., 2d Sess. 1 (1980), reprinted in 1980 Bankr. L. REP. (CCH) No. 30 (pt. 2), at 1. Errors enumerated in that report include mistakes in printing, spelling, punctuation, grammar, syntax, and numeration; incongruent provisions left after other material was removed; 
One such ambiguity pertains to consumer bankruptcy property exemptions. Section $522(\mathrm{~d})^{5}$ of the Code exempts certain

added provisions not completely integrated; and minor substantive matters either overlooked or postponed at the time of enactment. Id. at 1-2, reprinted in 1980 BANKR. L. RBP. (CCH) No. 30 (pt. 2), at 1-2. The proposed amendments to section 522 in the "technical amendments" bill currently before Congress are numerous, but pertain primarily to changes in phraseology to promote clarity and do not affect the issues addressed in this comment. See S. 863, 97th Cong., 1st Sess. $\$ 38$ (1981), reprinted in 1981 BANKR. L. REP. (CCH) No. 47, at 61-66 (extra ed.). However, S. 2000, 97th Cong., 1st Sess. § 7, 127 CoNG. RBC. S15,71215 (daily ed. Dec. 16, 1981), introduced in December 1981, provides for the abolition of federal exemptions altogether.

For commentary on the technical weaknesses of the Code, see, e.g., Butler, supra note 2, at 573-74; Evans, Recent Developments: Bankruptcy Code, 36 Bus. LAw. 1259, 1260-64 (1981); Kennedy, Foreword: A Brief History of the Bankruptcy Reform Act, 58 N.C.L. REv. 667, 678-79 (1980); Vukowich, Debtor's Exemption Rights Under the Bankruptcy Reform Act, 58 N.C.L. REv. 769, 783-85, 790, 794-96, 810-12 (1980); Comment, Good Faith in Chapter 13: A New Wild Card for Bankruptcy, 8 OHo N.U.L. Rev. 102, 106 (1981).

Two of the Code provisions quoted in this comment contain obvious errors in transcription. See infra notes 61,64 , and accompanying text.

11 U.S.C. \$ 522(d) (Supp. IV 1980):

The following property may be exempted under subsection (b)(1) of this section:

(1) The debtor's aggregate interest, not to exceed $\$ 7,500$ in value, in real property or personal property that the debtor or a dependent of the debtor uses as a residence, in a cooperative that owns property that the debtor or a dependent of the debtor uses as a residence, or in a burial plot for the debtor or a dependent of the debtor.

(2) The debtor's interest, not to exceed $\$ 1,200$ in value, in one motor vehicle.

(3) The debtor's interest, not to exceed $\$ 200$ in value in any particular item, in household furnishings, household goods, wearing apparel, appliances, books, animals, crops, or musical instruments, that are held primarily for the personal, family, or household use of the debtor or a dependent of the debtor.

(4) The debtor's aggregate interest, not to exceed $\$ 500$ in value, in jewelry held primarily for the personal, family, or household use of the debtor or a dependent of the debtor.

(5) The debtor's aggregate interest, not to exceed in value $\$ 400$ plus any unused amount of the exemption provided under paragraph (1) of this subsection, in any property.

(6) The debtor's aggregate interest, not to exceed $\$ 750$ in value, in any implements, professional books, or tools, of the trade of the debtor or the trade of a dependent of the debtor.

(7) Any unmatured life insurance contract owned by the debtor, other than a credit life insurance contract.

(8) The debtor's aggregate interest, not to exceed in value $\$ 4,000$ less any amount of property of the estate transferred in the manner specified in section $542(d)$ of this title, [pertaining to payment for life insurance by means of levy on the estate] in any accrued dividend or interest under, or loan value of, any unmatured life insurance contract owned by the debtor under which the insured is the debtor or an individual of whom the debtor is a dependent.

(9) Professionally prescribed health aids for the debtor or a dependent of the debtor.

(10) The debtor's right to receive-

(A) a social security benefit, unemployment compensation, or a local public assistance benefit;

(B) a veterans' benefit; 
property owned by a bankrupt ${ }^{6}$ from levy by his creditors. ${ }^{7}$ Paragraph (5) of that section provides that a debtor may exempt his "aggregate interest, not to exceed in value $\$ 400$ plus any unused amount of the [ $\$ 7500$ homestead] exemption provided under paragraph (1) of this subsection, in any property."B An overwhelming majority of courts ${ }^{9}$ have construed the phrase "any property" to

(C) a disability, illness, or unemployment benefit;

(D) alimony, support, or separate maintenance, to the extent reasonably necessary for the support of the debtor and any dependent of the debtor;

(E) a payment under a stock bonus, pension, profitsharing, annuity, or similar plan or contract on account of illness, disability, death, age, or length of service, to the extent reasonably necessary for the support of the debtor and any dependent of the debtor, unless-

(i) such plan or contract was established by or under the auspices of an insider that employed the debtor at the time the debtor's rights under such plan or contract arose;

(ii) such payment is on account of age or length of service; and

(iii) such plan or contract does not qualify under [the Internal Revenue Code].

(11) The debtor's right to receive, or property that is traceable to-

(A) an award under a crime victim's reparation law;

(B) a payment on account of the wrongful death of an individual of whom the debtor was a dependent, to the extent reasonably necessary for the support of the debtor and any dependent of the debtor;

(C) a payment under a life insurance contract that insured the life of an individual of whom the debtor was a dependent on the date of such individual's death, to the extent reasonably necessary for the support of the debtor and any dependent of the debtor;

(D) a payment, not to exceed $\$ 7,500$, on account of personal bodily injury, not including pain and suffering or compensation for actual pecuniary loss, of the debtor or an individual of whom the debtor is a dependent; or

(E) a payment in compensation of loss of future earnings of the debtor or an individual of whom the debtor is or was a dependent, to the extent reasonably necessary for the support of the debtor and any dependent of the debtor.

- This comment will use the terms "bankrupt," "debtor," and "consumer bankrupt" interchangeably, referring in each case to an individual petitioner for personal, as opposed to business, bankruptcy. An individual may choose between chapters 7 (liquidation, 11 U.S.C. §§ 701-766 (Supp. IV 1980)) and 13 (debt adjustment, id. $\S \S 1301-1330$ ). The exemptions discussed here are relevant only to chapter 7 liquidations.

' A bankrupt may choose between state and federal exemptions, unless the state concerned has barred the use of federal exemptions by statute. Id. $\$ 522(\mathrm{~b})$. As of this writing, 19 states had "opted out" of the federal exemption scheme: Alabama, Arizona, Florida, Georgia, Illinois, Indiana, Kansas, Kentucky, Louisiana, Maine, Maryland, Montana, Nebraska, Ohio, Oklahoma, South Dakota, Tennessee, Virginia, and Wyoming. Evans, supra note 4, at 1261; Me. Rev. Stat. Ann. tit. 14, § 4426 (Supp. 1981); Md. Cts. \& Jud. Proc. Code ANn. § 11-504(g) (Supp. 1981); Mont. Code ANN. § 31-2-106 (1981).

811 U.S.C. \& 522(d)(5) (Supp. IV 1980) (emphasis added).

- The Code's most controversial changes were to the bankruptcy court system. See Aaron, supra note 2, at 23-24. Under pre-Code law, federal "referees" presided over bankruptcy courts; their adjudications were appealable to the district courts. The new bankruptcy courts are adjuncts of the federal district courts, and federal bankruptcy judges pre- 
mean literally any property of the debtor's estate without restriction, thus allowing every debtor a $\$ 7900$ "grubstake"10 of property in any form. ${ }^{11}$ Only two courts, now both overruled, have construed "any property" to be restricted to property of the types specified in the other paragraphs of section 522(d), ${ }^{12}$ thus limiting debtors to those forms of "preferred property" traditionally protected by ex-

side; their decisions are appealable to the circuit courts. The circuit courts may appoint appellate panels of three bankruptcy judges to hear appeals from the bankruptcy courts. See 28 U.S.C. \$§ 151-160 (Supp. III 1979).

The bankruptcy court system is scheduled to become completely effective on April 1, 1984. See Pub. L. No. 95-598, $\$ 402,92$ Stat. 2549, 2682 (1978). During the present transition period, the new system generally is in effect except that the bankruptcy judges have not yet attained full federal judge status; appeals from bankruptcy judges may be taken by district courts, appellate panels, or circuit courts; and a pilot "federal trustee" program is in effect in 14 judicial districts. 28 U.S.C. $\$ \$ 581-585,587-589$ (Supp. III 1979). Full implementation has been cast in doubt by a recent case holding the bankruptcy judges' broad powers unconstitutional. Marathon Pipeline Co. v. Northern Pipeline Constr. Co., 12 Bankr. 946 (D. Minn. 1981), prob. juris. noted, 50 U.S.L.W. 3375 (U.S. Nov. 10, 1981) (No. 81-150).

10 The paragraph (5) exemption under the majority view has been labelled an "unfilled bin," In re Schuler, 13 Bankr. 478, 478 (Bankr. D. Mont. 1981); "general," Leech v. Nichols, 4 Bankr. 711, 715 (Bankr. E.D. Mich. 1980); a "grubstake," 3 Collier ON BanKRUPTCY, supra note 2, at I 522.02; a "wildcard," Lindsey, supra note 2, at 371 \& n.4; and a "catchall," Mapother, supra note 2, at 12.

${ }^{11}$ In re Smith, 640 F.2d 888 (7th Cir. 1981); In re LaFlamme, 14 Bankr. 21 (Bankr. 1st Cir. 1981) (Truth in Lending Act causes of action exempted under paragraph (5)); In re Schuler, 13 Bankr. 478 (bankr. D. Mont. 1981) (income tax refund and sum owed on a contract for deed exempted); In re Hilbert, 12 Bankr. 434 (Bankr. E.D. Pa. 1981) (real estate exempted); Chrystler v. Geresy (In re Brock), 10 Bankr. 67 (Bankr. W.D. Mich. 1981) (cause of action for an invalid sale exempted); Taylor v. Industrial Valley Bank, 8 Bankr. 578 (Bankr. E.D. Pa. 1981) (cash exempted); Smith v. Bank of Glenwood, 8 Bankr. 375 (Bankr. S.D. Cal. 1980) (cash exempted); In re Brosius, 7 Bankr. 811 (Bankr. C.D. Cal. 1980) (miscellaneous items, including four motor vehicles, exempted); In re Lowe, 7 Bankr. 248 (Bankr. E.D. Wash. 1980) (real estate exempted); Krupp, Meyers \& Hoffman v. Doyle (In re Laird), 6 Bankr. 273 (Bankr. E.D. Pa. 1980) (arbitration award exempted); In re Collins, 5 Bankr. 675 (Bankr. N.D. Cal. 1980) (credit union account exempted); Leech v. Nichols, 4 Bankr. 711 (Bankr. E.D. Mich. 1980) (income tax refund exempted); In re Cramer, 3 Bankr. 428 (Bankr. D. Ariz. 1980) (privately owned business inventory exempted); In re Upright, 1 Bankr. 694 (Bankr. N.D.N.Y. 1979) (privately owned business inventory exempted).

Courts following the majority view in dicta while using paragraph (5) to exempt only property specified elsewhere in section 522(d) include Travelers Ins. Co. v. Angus, 9 Bankr. 769 (Bankr. D. Or. 1981) (ring exceeding section 522(d)(4) limit in value); Webber v. Credithrift of Am., Inc., 7 Bankr. 580 (Bankr. D. Or. 1980) (household goods); Beard v. Dial Plan, 5 Bankr. 429 (Bankr. S.D. Iowa 1980) (household goods); Credithrift of Am., Inc. v. Dubrock, 5 Bankr. 353 (Bankr. W.D. Ky. 1980) (automobile used as a tool of trade); Boozer v. Kennesaw Fin. Co., 4 Bankr. 524 (Bankr. N.D. Ga. 1980) (household goods); Bagley v. Robert Scott Gordon, Inc., 1 Bankr. 116 (Bankr. E.D. Pa. 1979) (automobile).

${ }_{12}$ In re Smith, 5 Bankr. 500 (C.D. Ill. 1980), rev'd, 640 F.2d 888 (7th Cir. 1981); LaFlamme v. Finance Am. Corp., 10 Bankr. 792 (Bankr. D.R.I.), rev'd sub nom. In re La Flamme, 14 Bankr. 21 (Bankr. 1st Cir. 1981). 
emption statutes. ${ }^{13}$

The disparity in the relative degree of support for these two views belies both the ambiguity of the statutory language and the absence of any direct discussion of the issue in the legislative history. This comment argues that the minority view, though superficially a countertextual reading of paragraph (5), is in fact closer to the apparent congressional intent. After outlining the traditional forms and underlying principles of property exemptions and contrasting these concepts with the majority approach, the comment analyzes the language and legislative history of paragraph (5) and reviews the practical considerations implicated by the conflicting interpretations. The comment concludes that Congress intended to provide the traditional scheme of exemptions authorized by the minority interpretation of paragraph (5) and that it never endorsed, implicitly or explicitly, the majority grubstake approach.

\section{Bankruptcy Exemptions in History and in CurRent Practice}

\section{A. Traditional Forms and Principles}

Although harsh debt collection procedures have existed since antiquity, ${ }^{14}$ exemption of some types of debtor property from cred-

1s Neither the courts nor commentators have attempted to determine the precise effect of the minority view on the $\$ 400$ allowance contained within paragraph (5) itself. A rigorous application of the minority approach would require that the $\$ 400$ allowance, like the $\$ 7500$ homestead overflow, be restricted to items specifically enumerated in section 522(d), thereby denying the debtor any outright cash exemption. A better reading, although one more diffcult to sustain under the statutory language, would provide that "any property" is in fact nonrestrictive, but extends only to the $\$ 400$ allowance, while the unused amount of the homestead exemption is restricted to other specifically exempted property. Under the latter reading, paragraph (5) closely adheres to the cash or "general" exemption allowances of many state statutes, see infra note 20 , to the liquid assets exemption of the Uniform Exemptions Act ("UEA") that served as the basis for the Code exemptions, see infra notes 72, 93, 96, and accompanying text, and to the reductions imposed by Congress on the other UEA exemption allowances, see infra notes 108-10 and accompanying text. Because the plain words of paragraph (5) in isolation do not support this reading, it is tempting to assume a drafting error, and there is some evidence that supports that assumption. See infra note 50 and accompanying text. The discussion in this comment applies to both readings except as indicated infra notes $50,110$.

Professor William Vukowich, though siding with the majority, suggests that paragraph (5) might be read to bar application of the unused homestead exemption to property specified in section $522(\mathrm{~d})$, rather than requiring such application as urged by the minority, or permitting it as urged by the majority. Vukowich, supra note 4 , at $780-82$. This unlikely interpretation is rejected under the minority view advocated here, but has some application to later discussion in this comment. See infra note 47 and accompanying text.

14 See, e.g., Countryman, A History of American Bankruptcy Law, 81 Coм. L.J. 226, 
itor levy has an equally lengthy history. ${ }^{15}$ Under English law statutory provision for bankruptcy is a relatively recent phenomenon, but was early accompanied by some-if minimal—specific property exemptions. ${ }^{16}$

American statutes have followed suit. The first three federal bankruptcy statutes each exempted certain specific items of property. ${ }^{17}$ The Bankruptcy Act of 1898, the fourth and last pre-Code bankruptcy statute, incorporated state exemption provisions into the federal scheme. ${ }^{18}$ Although the state statutes varied widely in

226-27 (1976) (tracing development from 450 B.C. to 1787 of sanctions against debtors, including dissection at the option of creditors, debt slavery, imprisonment, and seizure of property); Kennedy, Reflections on the Bankruptcy Laws of the United States, 76 W. VA. L. REv. 427, 428-34 (1974) [hereinafter cited as Reflections] (describing historical punishments and stigmatizations of delinquent debtors); Kennedy, Limitations of Exemptions in Bankruptcy, 45 IowA L. REv. 445, 446-47 (1960) [hereinafter cited as Limitations]; Comment, Personal Property Exemptions and the Uniform Exemptions Act, 1978 B.Y.U.L. REv. 462, 466-67.

${ }^{16}$ E.g., Rombauer, Debtors' Exemption Statutes-Revision Ideas, 36 Wash. L. REv. 484, 485 (1961) (citing a Roman civil statute of 312 A.D. that prohibited seizure of agricultural implements, cattle, and slaves when payment of taxes would be delayed, and noting the "extensive list of exemptions" in the eighteenth century Spanish civil code).

16 See, e.g., Countryman, supra note 14, at 227 (noting the development of English bankruptcy law from 1542 until the first provision for the exemption of wearing apparel and a conditional sum of cash in 1705); Vukowich, Debtors' Exemption Rights, 62 Gko. L.J. 779, 782 (1974) ("Under early English common law, canons of decency required exemptions of debtors' necessary clothing. Later English laws recognized exemptions of bare essentials, clothing, bedding, and tools of trade, but reflected little tolerance for debtors beyond recognizing the need to preserve some minimal assets for the debtors' survival.") (footnote omitted).

17 The Bankruptcy Act of 1800, ch. 19, § 5, 2 Stat. 19, 23 (repealed 1803), exempted the wearing apparel and necessary "beds and bedding" of the debtor and his family. The Bankruptcy Act of 1841, ch. 9, § 3, 5 Stat. 440, 443 (repealed 1843), exempted "the necessary household and kitchen furnishings, and such other articles and necessaries" to an aggregate value limit of $\$ 300$, plus the wearing apparel of the debtor and his family. The Bankruptcy Act of 1867, ch. 176, § 14, 14 Stat. 517, 522-23 (repealed 1878), allowed exemption of household and kitchen necessaries to an aggregate value limit of $\$ 500$; the debtor's wearing apparel, arms, and uniforms; and, most significantly, any other property exempted by state law.

1s Bankruptcy Act of 1898, ch. 541, $\S 6$ a, 30 Stat. 544, 548 (superceded 1978). Federal incorporation of varying state exemptions has long been held not to violate the constitutional mandate of "uniform" federal bankruptcy laws, U.S. CoNST. art. I, $\S 8$, cl. 4, on the ground that the required uniformity is geographical rather than personal. Exemptions may vary from state to state as long as they are uniformly applied within a given state. Hanover Nat'l Bank v. Moyses, 186 U.S. 181, 188-90 (1902).

Federal exemptions from creditor levy existed in certain federal nonbankruptcy statutes concurrent with the 1898 Act and still exist today. Most protect various forms of personal income, generally that paid by the federal government. See, e.g., 15 U.S.C. § 1673 (Supp. IV 1980) (limits on wage garnishment); 38 U.S.C. $\S 3101$ (1976) (veteran's benefits, also exempted under section 522(d)(9) of the Code); 42 U.S.C. $\$ 407$ (1976) (social security benefits, also exempted under section 522(d)(9) of the Code); 46 U.S.C. $\$ 601$ (1976) (wages of 
aggregate property value exempted and in the practicality and modernity of their exemption provisions, virtually all adhered to the specified property approach. ${ }^{19}$ As of 1978 , the grubstake approach was implemented fully in only two states, ${ }^{20}$ despite frequent academic commentary in its favor. ${ }^{21}$

Bankruptcy exemptions traditionally have included the debtor's homestead, household goods, wearing apparel, and tools of

seamen). Certain federal nonbankruptcy statutes also provide specific property exemptions. See infra note 32. For a discussion of nonbankruptcy federal exemptions while the 1898 Act was in effect, see Vukowich, The Bankruptcy Commission's Proposal Regarding Bankrupts' Exemption Rights, 63 CALIF. L. Rev. 1439, 1445-51 (1975).

19 Most commentators criticize state exemption statutes for being outmoded, niggardly, and confined to rigid property specifications. See, e.g., D. Stanley \& M. GrRth, BanKRuptcy: Problem, Process, Reform 81-84 (1971); Countryman, For a New Exemption Policy in Bankruptcy, 14 RuTGers L. Rev. 678, 681-84 (1960); Joslin, Debtors' Exemption Laws: Time for Modernization, 34 IND. L.J. 355 (1959); Plumb, The Recommendations of the Commission on the Bankruptcy Laws-Exempt and Immune Property, 61 VA. L. Rev. 1, 4-18, 152-53 (1975); Rombauer, supra note 15, at 484; Note, Bankruptcy Exemptions: $A$ Full Circle Back to the Act of 1800?, 53 CoRnell L. REv. 663, 665-71 (1968); Comment, Bankruptcy Exemptions: Critique and Suggestions, 68 YALE L.J. 1459, 1465-70 (1959). But see Vukowich, supra note 16, at 797-832 (arguing that some state statutory exemptions are too generous). On the history of state exemption statutes, see generally C. WARREN, BankRUPTCY IN UNITED STATES History 146-52 (1935); Vukowich, supra note 16, at 783-88.

${ }^{20}$ Though now out of date, a good thumbnail sketch of state exemption statutes in effect at the time of the Code's enactment, without discussion of the homestead exemption provisions, is provided in A. Milberg \& H. Shain, How To Do Your Own Bankruptcy 4493 (1978). At that time, the constitution of North Carolina exempted $\$ 500$ of personalty to be chosen by the debtor, with no other provision for exemption of personal property, N.C. CoNST. art. X, $\S 1$, and Florida debtors were permitted a grubstake of $\$ 1000$ in a similar scheme under Fla. Stat. ANN. § 222.07 (1977) and Fla. Const. art. X, § 4. The remaining states and the District of Columbia all specified some categories of exempt personal property, although at least one state permitted a choice between a grubstake and specified property exemptions. MD. CTS. \& JuD. Proc. Code ANN. \$§ 11-504-05 (1980) (permitting choice of $\$ 1000$ in "any property" or otherwise specified property). The largest cash (or "general") exemptions, other than those of the jurisdictions cited immediately above, were Georgia's $\$ 5000$ allowance for “any property," Virginia's $\$ 3500$ allowance, Tennessee's $\$ 2500$ allowance, and New Mexico's $\$ 1500$ allowance. See A. Milberg \& H. Shain, supra, at 44-93. Of the 51 jurisdictions listed, only 12 had "general" exemptions exceeding $\$ 700$, while 29 had no such exemption in any amount. States offering a "general" exemption frequently required that the debtor exercising the exemption be either a homeowner or head of family and offered reduced or no exemptions to single debtors. See id.

Since 1978 many states have changed their exemption statutes. The most marked trend has been to "opt out" of the federal scheme, see supra note 7, but some states have also made their exemptions more liberal. See, e.g., MD. CTs. \& Jud. Proc. Code AnN. § 11504(b)(5) (Supp. 1981) (\$3000 in "any property" exempted, up from $\$ 1000$ in 1978). A compilation of current state exemption statutes without commentary is contained in 1981 BANKR. L. REP. (CCH) 951.

${ }^{21}$ See, e.g., Countryman, supra note 19, at 746-48; Plumb, supra note 19, at 18-19, 152 53; Note, supra note 19, at 671; Comment, supra note 19, at 1507-10. Cf. Joslin, supra note 19 , at 358-60 (advocating "semi-flexible" exemptions). 
trade. ${ }^{22}$ Most modern exemption statutes also contain allowances for various forms of personal income, life insurance, and a motor vehicle, but otherwise differ from the traditional statutes only in their broader definitions of essentially the same "preferred" categories. $^{23}$ Allowances for exemptions of cash, other liquid assets, or "any property" at the debtor's election are not unusual, but are generally quite small. ${ }^{24}$

Exemptions historically have been perceived as having mutually supportive humanitarian and practical purposes: protection of the debtor and his family from destitution, debtor rehabilitation, and avoidance of the need for direct public support. ${ }^{25}$ To ensure that distribution of assets to creditors is reduced as little as possible, exemptions are minimal, limited to those "necessaries" actually needed for continued productive existence. ${ }^{26}$

In the modern context, the justifications of creditor protection and reduction of the public charge are attenuated by the operation of the market for consumer credit. The cost of consumer bankruptcies, though apparently falling on those creditors whose claims are discharged for reduced or no payment, ${ }^{27}$ is in fact indirectly borne by society at large. By increasing the price of credit to offset bad debt losses, creditors disperse the ultimate cost of bankruptcy over those consumers using credit without default. ${ }^{23}$ Property exemptions of any kind reduce the pool of debtor assets available for creditor levy, which increases creditor losses and, therefore, the cost of credit. ${ }^{2 \theta}$

This modern development does not invalidate the traditional choices of preferred property, but helps indicate why only certain property is exempt. By imposing a social cost in the form of an

22 See, e.g., Plumb, supra note 19, at 14-96; Rombauer, supra note 15, at 490-99; Vukowich, supra note 16 , at 797-832.

28 Vukowich, supra note 16, at 797-832. See also Joslin, supra note 19, at 360, 368-72.

24 Joslin, supra note 19, at 360, 368-72. See also supra note 20.

13 See, e.g., Curry v. Associates Fin. Servs., 5 Bankr. 282, 293 (Bankr. N.D. Ohio 1980), aff'd, 11 Bankr. 716 (N.D. Ohio 1981); Centran Bank v. Ambrose, 4 Bankr. 395, 401 (Bankr. N.D. Ohio 1980); Joslin, supra note 19, at 355; Rombauer, supra note 15, at 486; Vukowich, supra note 16, at 782-88; Comment, supra note 19, at 1502-03.

28 Vukowich, supra note 16, at 831-32; Vukowich, supra note 4, at 771.

${ }^{27}$ See, e.g., Curry v. Associates Fin. Servs., 5 Bankr. 282, 293 (Bankr. N.D. Ohio 1980) (exemption statutes are designed to shift "burdens of social welfare from community to creditors"), aff'd, 11 Bankr. 716 (N.D. Ohio 1981).

${ }^{28}$ Credit Rzsearch Center, Monograph No. 23, Consumer Bankruptcy Study (vol. 1) 91-94 (1982) [hereinafter cited as Bankruptcy Study]; D. Stanley \& M. Girth, supra note 19 , at 37 .

20 Comment, supra note 19, at 1459. 
increased price of credit, consumer bankruptcies present a choice between increasing that cost by permitting property exemptions and enabling debtors to remain relatively self-supporting, or reducing that cost by denying exemptions and undertaking the alternative cost of supporting impoverished debtors by direct transfer payment. $^{30}$ Thus, the choice of what property to exempt is not based only on the importance of particular items to the debtor in supporting and rehabilitating himself. In attempting to maximize social welfare, the choice also should consider the value of the exempted property in the hands of the debtor as compared with its value when resold by creditors. The traditional forms of exempted property are almost invariably either items of high replacement and low resale price, or items having a particular sentimental value that is unique to the owner and ignored on the open market. Clothing and household goods, the two oldest forms of preferred property in bankruptcy, are the classic examples of property meeting both these criteria. Tools of trade have a greater value assembled for the use of a particular tradesman than disbursed for resale to others. As demonstrated by the common law rule of specific performance in real estate contracts, ${ }^{31}$ a homestead is considered a unique item of property of special value to the owner. The more debatable property exemptions generally fail to meet clearly the criterion of greater value in the debtor's hands than in the creditor's. For example, the obvious sentimental value of jewelry is counterbalanced by its ease of resale; automobiles, once depreciated, arguably are interchangeable and certainly have an established resale market; cash and other liquid assets are completely fungible.

In sum, the conventional forms of exempted property seem well chosen both to balance the traditional justifications of debtor protection, creditor payment, and conservation of the fisc, and to meet the modern concern of maximizing social welfare in the context of consumer credit. As of 1978, all federal, and the overwhelming majority of state, bankruptcy exemption statutes were limited to such property. ${ }^{32}$

so Id. at 1497-1502. A third "alternative" would be to reduce debtors to poverty by levy without providing for any subsequent support. This option obviously is not viable in modern society.

3i See Murray on Contracts § 220, at 441 (2d rev. ed. 1974).

s2 See supra notes 18-21 and accompanying text. It is significant that federal nonbankruptcy statutes addressing exemption of tangible property generally provide a detailed specified property exemption scheme. See, e.g., 26 U.S.C. § 6334(a) (1976) (property exempted 


\section{B. Exemptions Under Paragraph (5)}

It was against this background that Congress enacted the Code. The property exemptions it provides are generally of the traditional types, and the dollar value of most are no more than average when compared with similar state statutes. ${ }^{33}$ The one striking exception to this rule of moderation is the asserted $\$ 7900$ grubstake exemption of paragraph (5). ${ }^{34}$ The majority-view courts have permitted exemption under paragraph (5) of large amounts of property not traditionally preferred, including cash amounts of $\$ 800,{ }^{36} \$ 11,000,{ }^{36}$ and $\$ 14,592,{ }^{37}$ privately owned business inventories worth $\$ 5582^{38}$ and $\$ 10,000 ;{ }^{38}$ an arbitration award of $\$ 6700 ; ;^{40}$ a credit union account of $\$ 7900 ; 41$ unimproved real estate worth $\$ 1350$ and $\$ 1800 ;{ }^{42}$ rental property worth $\$ 15,000 ; ;^{43}$ and a debtor's interest in "a 1977 Dodge Van, a cash register, an air pump, a 1963 El Con Mobile Home, a 1969 Kawasaki motorcycle, a 1974 AMC motor vehicle, and a Macaw parrot, for a total value of $\$ 3,500 . " 44$

from tax levy); 42 U.S.C. $\$ 1382 b$ (1976 \& Supp. III 1979) (property disregarded in calculating resources of supplemental security income recipients); cf. 45 C.F.R. 233.20(a)(3)(i) (1980) (property allowances for state welfare program recipients).

3s Hughes, supra note 2, at 1029-30; Vukowich, supra note 4, at 778.

st See cases cited supra note 11; Hughes, supra note 2 , at $1030 \&$ n.41. Under the majority interpretation, paragraph (5) gives all debtors a $\$ 7900$ "general exemption." In re Smith, 640 F.2d 888, 891 (7th Cir. 1981). As of 1978, this figure was over 50\% larger than the then-largest state general exemption of $\$ 5000$, and over $1000 \%$ larger than the usual general exemption, where one existed at all, of less than $\$ 700$. Twenty-nine states had no such exemption in any amount. See supra note 20.

${ }^{25}$ Taylor v. Industrial Valley Bank, 8 Bankr. 578, 580 (Bankr. E.D. Pa. 1981).

30 In re Schuler, 13 Bankr. 478, 480 (Bankr. D. Mont. 1981) (total of income tax refunds and amount owed on a contract for deed allowed as exempt for joint debtors).

${ }^{37}$ Smith v. Bank of Glenwood, 8 Bankr. 375, $377-79$ (Bankr. S.D. Cal. 1980) (total cash amount allowed as exempt for joint debtors).

ss In re Upright, 1 Bankr. 694, 701-02 (Bankr. N.D.N.Y. 1979).

39 In re Cramer, 3 Bankr. 428, 429 (Bankr. D. Ariz. 1980) (joint debtors).

40 Krupp, Meyers \& Hoffman v. Doyle (In re Laird), 6 Bankr. 273, 274, 276 (Bankr. E.D. $\mathrm{Pa}$. 1980) (award accrued prior to filing of bankruptcy petition but paid afterwards).

41 In re Collins, 5 Bankr. 675, 676 (Bankr. N.D. Cal. 1980).

12 In re Lowe, 7 Bankr. 248, 249-51 (Bankr. E.D. Wash. 1980) (consolidation of two cases, one holding unimproved real estate exemptable under paragraph (5)).

43 In re Hilbert, 12 Bankr. 434, 435-36 (Bankr. E.D. Pa. 1981).

4t In re Brosius, 7 Bankr. 811, 812 (Bankr. C.D. Cal. 1980).

Paragraph (5) also has been employed to exempt "overflow" from the other exemption provisions of section 522(d), typically to allow additional exemption of household goods and furnishings, see Webber v. Credithrift of Am., Inc., 7 Bankr. 580, 582 (Bankr. D. Or. 1980); Beard v. Dial Plan, 5 Bankr. 429, 430 (Bankr. S.D. Iowa 1980); Boozer v. Kennesaw Fin. Co., 4 Bankr. 524, 526-27 (Bankr. N.D. Ga. 1980); automobiles, see Bagley v. Robert Scott Gordon, Inc., I Bankr. 116, 118 (Bankr. E.D. Pa. 1979); and tools of trade, see Credithrift of Am., Inc. v. Dubrock, 5 Bankr. 353, 355-56 (Bankr. W.D. Ky. 1980). This use of paragraph 
Although debtors owning such relatively extensive assets are apparently unusual, ${ }^{45}$ these results are strikingly incongruous compared with the traditional "necessaries" exempted in bankruptcy, and they also find little support in the principles underlying the exemption of preferred property..$^{16}$ Only by limiting a debtor to a homestead or other preferred property in compiling the maximum exemption available under paragraph (5) _as does the minority interpretation-are the basic policies supporting exemption of preferred property vindicated. Under the majority approach, two debtors who possess radically different amounts of preferred property can still receive the same total dollar amount in exemptions; if this outcome is desirable, it is difficult to understand why the Code provides a list of preferred property at all. ${ }^{47}$ Because the practical effects of the majority grubstake approach diverge so markedly from the underlying principles of debtor exemptions, a careful analysis of the statutory language and legislative history of paragraph (5) should be made to determine if they compel such unlikely results.

(5) accords with the approach advocated by the minority-view courts, though the property categories are sometimes stretched to the outer limits of reasonable definition. E.g., Hagerman v. Dial Fin. Co., 9 Bankr. 412, 413 (Bankr. W.D. Mo. 1981) (television set and nonoccupational tools held to be household furnishings absent any indication that they were not ordinary items found in most households); Coleman v. Lake Air Bank, 5 Bankr. 76, 79 (Bankr. M.D. Tenn. 1980) (stereo system held to be household furnishing "regardless of how elaborate").

${ }^{45}$ On the variance between the reported cases and the average bankruptcy proceeding, see Shuchman, An Attempt at a "Philosophy of Bankruptcy," 21 U.C.L.A. L. Rev. 403, 40509 (1974). See also infra notes $128-30$ and accompanying text.

46 Supra notes 25-31 and accompanying text.

67 Vukowich, supra note 4, at 780-81, was concerned that paragraph (5) might be misinterpreted to bar debtors from utilizing the homestead exemption overflow for additional exemption of property specified in section 522(d). He noted that "the list of property in section 522(d) is so comprehensive of the types of property that are designed to fulfill the policy goals of the exemption laws that it would undermine the purpose of the subsection to require debtors to select unlisted property." Id. at 781. The majority view, which permits rather than requires debtors to retain unlisted property, is objectionable for the same reason: both views "undermine the purposes of the subsection." In contrast, the minority approach encourages retention, and even acquisition, of preferred property, because debtors are permitted to exchange nonexempt property on the eve of bankruptcy. See infra note 101 and accompanying text. The majority approach is indifferent to this important policy. Judge Hughes has observed:

The policy implication of the merger of the residential allowance and the unrestricted exemption is that highly favored property, such as a homestead or burial plot, receives the same treatment under section 522(d) as less favored property such as country club memberships, ski cabins, gambling casino chips, wine cellars, and yachts.

Hughes, supra note 2, at 1031 (footnotes omitted). 


\section{The Statutory Language}

Arguing that bankruptcy statutes are to be construed liberally, ${ }^{48}$ the majority courts simply and persuasively contend that the plain language of paragraph (5) exempts "any property" without limitation. ${ }^{49}$ Paragraph (5), examined in isolation, provides no immediately apparent statutory ground on which to oppose this position, ${ }^{50}$ for courts should construe statutory language according

48 E.g., In re Smith, 640 F.2d 888, 891 (7th Cir. 1981); In re Ancira, 5 Bankr. 673, 674 (Bankr. N.D. Cal. 1980). This general principle is of little practical use in statutory interpretation and its meaning is diluted by dicta equally vague but different in effect. See, e.g., In $r e$ Time Sales Fin. Corp., 474 F.2d 1197, 1201 (3d Cir. 1971) (one of the "chief purposes" of bankruptcy law is to effect an efficient settlement of the debtor's estate); Quigley v. Kimbrough, 395 F.2d 100, 103 (5th Cir. 1968) ("the broad purpose of the Bankruptcy Act is to bring about an equitable distribution of the bankrupt's estate") (quoting United States v. Embassy Restaurant, 359 U.S. 29, 31 (1959)); Klebanoff v. Mutual Life Ins. Co., 362 F.2d 975, 979-80 (2d Cir. 1966) ("our guidelines of interpretation are relatively narrow" when construing a bankruptcy exemption for insurance). More significantly, much of the case law involving liberal construction of bankruptcy exemption statutes originated between 1898 and 1978, when exemptions were governed by state law and the federal courts were constrained by a deference inapplicable to the construction of federal law. See, e.g., Williams v. Wirt, 423 F.2d 761, 763 (5th Cir. 1970) ("In applying the exemption laws of a state the federal courts follow the construction placed thereon by the courts of the state.") (citations omitted). See also Holahan \& Hemmings, Judicial Expansions of Exemptions in Bankruptcy, 80 CoM. L.J. 102, 103 (1975) (federal courts purporting "to control and vary the state law of property" in bankruptcy violate the federal bankruptcy statute). Additionally, liberal construction of state exemption statutes was necessitated in part by their frequently outmoded or niggardly property specifications. See Kennedy, Limitations, supra note 14, at 448 \& n.13; Note, supra note 19, at 670 . This last consideration is no longer valid, given the modernity and liberality of the exemption provisions of the Code.

40 See, e.g., In re Smith, 640 F.2d 888, 893 (7th Cir. 1981) (holding that "Congress meant to give the general exemption as broad an application as the language it chose"); In re LaFlamme, 14 Bankr. 21, 22-23 (Bankr. 1st Cir. 1981) (unlikely that the phrase "any property" would have been chosen to indicate an intent to "limit the application of the subsection"); Taylor v. Industrial Valley Bank, 8 Bankr. 578, 580 (Bankr. E.D. Pa. 1981) (absent express language to the contrary, "common sense dictates that the phrase 'any property' includes cash").

so A ground not immediately apparent is the substantial possibility that paragraph (5) contains a drafting error. This suggestion is made plausible not only by the existence of the ambiguity itself, but also by the fact that paragraph (5) was drafted as a deviation from the otherwise comprehensive scheme of the Uniform Exemptions Act, see infra notes 72, 93, 96, and accompanying text, and thus it is all too likely that the section was poorly integrated with the surviving provisions. Furthermore, the one direct explanation of paragraph (5) provided by Congress sets off the general exemption from the unused portion of the homestead exemption with a comma, while the statute as enacted did not contain the comma. Compare infra text accompanying note 96 with supra note 5 . With the comma present, the text more easily supports an allowance of a $\$ 400$ general exemption without restriction, and a homestead overflow exemption restricted to the property specified in section 522 (d). See supra note 13. An error in transcription involving a comma, as well as far more serious drafting shortcomings, is not unlikely given the widely recognized failings of the Code's language. See supra note 4. 
to its plain meaning in light of common usage whenever possible. ${ }^{\text {11 }}$ Paragraph (5) cannot, however, be analyzed in a vacuum. ${ }^{52}$

\section{A. Section 522}

When paragraph (5) is viewed within the context of section 522 , the analysis becomes more complex. First, some significance should attach to the placement of paragraph (5) within a series of paragraphs listing exempt property. ${ }^{\text {ss }}$ Second, section 522(b)(1) provides that a debtor taking the federal exemptions may exempt only "property that is specified under subsection (d) of this section." "T4 The term "specified" suggests that reference should be made to the specific enumeration of property found in the eleven paragraphs of section 522(d). Property not specifically listed therein is arguably not "property" within the meaning of the section. Although no majority court has countered this argument directly, ${ }^{\text {ss }}$ the most likely response is that $\$ 7900$. of "any property" is itself a specific listing despite its indefinite components. This response is unsatisfying, however, in the face of the painstaking specificity displayed in the other exemptions in section 522(d).

This very specificity suggests a third argument in favor of the

s1 "A fundamental canon of statutory construction is that, unless otherwise defined, words will be interpreted as taking their ordinary, contemporary, common meaning." Perrin v. United States, 444 U.S. 37, 42 (1979) (citation omitted).

52 "[W]e must always be mindful that the interpretation of a statute should not hinge on an isolated clause or phrase in a particular section, but should consider the whole statute as well as the objects and policy behind its enactment." In re Beaver, 2 Bankr. 337, 339 (Bankr. S.D. Cal. 1980) (citing Kokoszka v. Belford, 417 U.S. 642, 650 (1974)).

ss LaFlamme v. Finance Am. Corp., 10 Bankr. 792, 793, 794 (Bankr. D.R.I.), rev'd sub nom. In re LaFlamme, 14 Bankr. 21 (Bankr. 1st Cir. 1981). Under the principle of ejusdem generis, the "any property" term of paragraph (5) could be restricted to only those forms of property enumerated in the preceding four paragraphs, most of which fall into the traditional categories of exempted property. See text of statute, supra note 5 . The related canon of noscitur a sociis suggests that paragraph (5) "property" is confined to the subject matter of the references that surround it-the specific property exemptions of section 522(d).

${ }^{54} 11$ U.S.C. \& 522(b)(1) (Supp. IV 1980) (emphasis added).

ss In Leech v. Nichols, 4 Bankr. 711, 715 (Bankr. E.D. Mich. 1980), the court apparently was presented with the argument that section $522(b)(1)$ restricts paragraph (5) "other property" to property exempted under either state or federal law. The court noted that the argument "carries weight and is appealing in certain respects," but rejected it on the ground that the Code clearly presents state and federal exemptions as alternatives. Id. at 715-16. Later in the opinion, the court also rejected the section $522(b)(1)$ argument without reference to state law, stating only that such an interpretation "burdens unduly the meaning suggested by the dictionary definition and common usage of the english [sic] language." Id. at 717. The opinion therefore fails to staté exactly what argument was presented in support of the minority, but in any event it does not specifically refute the argument based on section $522(b)(1)$. 
minority view. The majority interpretation of paragraph (5) renders the homestead exemption of section 522(d)(1) superfluous because its $\$ 7500$ allowance is incorporated into paragraph (5)'s exemption of "any property." Such a result violates the principle that a statute must be read so as to avoid making any portion superfiuous. ${ }^{57}$ The result is particularly incongruous given the detailed property descriptions and limitations evident in all other paragraphs of section 522(d), but unaccountably abandoned in paragraph $(5)^{58}$ - even though that paragraph contains potentially the largest single exemption in section $522(\mathrm{~d}){ }^{\mathrm{s}}{ }^{\mathrm{\theta}}$ This criticism of the majority approach has been met only with the lame observation that " "even the most basic general principles of statutory construction must yield to clear contrary evidence of legislative intent." "Bo

\section{B. Sections 522 and 541}

Section $541(a)(1)$ defines "[p]roperty of the estate" to be "all legal or equitable interests of the debtor in property as of the commencement of the case."

se LaFlamme v. Finance Am. Corp., 10 Bankr. 792, 794 (Bankr. D.R.I.), rev'd sub nom. In re LaFlamme, 14 Bankr. 21 (Bankr. 1st Cir. 1981); Hughes, supra note 2, at 1031.

${ }^{67}$ "In construing a statute we are obliged to give effect, if possible, to every word Congress used." Reiter v. Sonotone Corp., 442 U.S. 330, 339 (1979) (citation omitted).

ss But see Chrystler v. Geresy (In re Brock), 10 Bankr. 67, 70 (Bankr. W.D. Mich. 1981):

As for the argument that a "spillover" is inconsistent with the careful delineation of types and amounts of property exemptable under the other provisions of Section 522(d), one can think of many cases where there would be no inconsistency at all, involving debtors with homestead equities equalling or exceeding the amounts allowed by Section 522(d)(1). It was also rational for Congress to allow the "spillover" for debtors with little or no homestead equity ....

This argument, though forcefully made, begs the question. Both the majority and the minority views provide a "spillover" for all debtors. See infra notes 98-103 and accompanying text.

so The $\$ 7900$ amount in paragraph (5) is larger than any other specified in section 522(d). The only comparable amounts are the $\$ 7500$ personal injury award exemption in paragraph $11(\mathrm{~d})$ and the $\$ 4000$ life insurance contract exemption in paragraph (8). The $\$ 7500$ homestead exemption of paragraph (1) is, of course, included in paragraph (5).

${ }^{60}$ In re LaFlamme, 14 Bankr. 21, 25 (Bankr. 1st Cir. 1981) (quoting National R.R. Passenger Corp. v. National Ass'n of R.R. Passengers, 414 U.S. 453, 458 (1974)).

${ }^{61} 11$ U.S.C. $\& 541(\mathrm{a})(1)$ (Supp. IV 1980) provides in pertinent part:

\$51. Property of the estate

(a) The commencement of a case under under [sic] section 301, 302, or 303 of this title [pertaining to voluntary, joint, and involuntary cases] creates an estate. Such estate is comprised of all the following property, wherever located:

(1) Except as provided in subsections (b) and (c)(2) of this section [pertaining to trusts], all legal or equitable interests of the debtor in property as of the com- 
stressed that there is no reason to differentiate between the uses of the term "property" in section 541 and in section 522, and that the all-inclusive definition in section 541 thus applies to paragraph (5) as well. ${ }^{62}$

There are three responses to this contention. First, section 541 only provides for and defines "[p]roperty of the estate"; it makes no reference to section 522 or to property exemptions. Thus its applicability to section 522 in general and to paragraph (5) in particular is far from clear. ${ }^{63}$ Second, even if it were to be argued that section 541 implicitly refers to section 522, Congress took special care to avoid such definitional transplants. The "Rules of Construction" contained in section 102 provide that "a definition, continued [sic] in a section of this title that refers to another section of this title, does not, for the purpose of such reference, affect the meaning of a term used in such other section." of the Code contains a list of definitions that apply throughout the Code, and "property" is not included among those defined terms. ${ }^{.5}$

mencement of the case.

${ }^{62}$ See, e.g., In re Smith, 640 F.2d 888, 890-92 (7th Cir. 1981); Leech v. Nichols, 4 Bankr. 711, 717 (Bankr. E.D. Mich. 1980) ("'Property,' as modified by the words 'of the estate' and the word 'any' cannot have such radically different meanings.").

6s Section 522 does contain a reference to section 541 , but it is not helpful to the majority position. Section 522(b) provides that a debtor may exempt property in accordance with section $522(\mathrm{~d})$ or the appropriate state law, "[n]otwithstanding section 541 of this title." 11 U.S.C. § 522(b) (Supp. IV 1980). The use of the term "notwithstanding" indicates that section 541 has no direct bearing on the determination of exemptions under section 522 .

B4 11 U.S.C. $\S 102(8)$ (Supp. IV 1980). This provision contains eight rules, the last of which is cited here. The error indicated generally is read as "contained." Collrer ON BANKRUPTCY, supra note 2 , at app. 1 \$ 102(8). Rule (8) was inserted into the proposed text of the Code during the final reconciliation of the competing House and Senate versions. See infra note 92 and accompanying text. For a rather opaque explanation of the rule, see 124 ConG. REc. 32,392, 32,393-94 (1978) (remarks of Rep. Edwards), reprinted in 1978 U.S. CoDE Cong. \& AD. News 6436, 6440.

B5 11 U.S.C. $\$ 101$ (Supp. IV 1980). Forty terms are defined in this section, including such basic terms as "claim," id. § 101(4); "creditor," id. § 101(9); "debt," id. § 101(11); "debtor," id. § 101(12); and "person," id. § 101(30). The omission of the term "property" from such an inclusive list suggests that the term is not intended to have only one specific meaning throughout the Code.

It should be noted that elsewhere in the Code, "property" is defined differently than in section 541. For example, 11 U.S.C. \& 1306 (Supp. IV 1980) provides that the "[p]roperty of the estate" applicable to debt adjustments contains, "in addition to the property specified in section 541 of this title," interests that the debtor acquires after the commencement of the case. Although this additional definition does not support the minority position directly in that it is broader than that of section 541, it does suggest that the definition of property in section 541 does not extend throughout the Code. 


\section{Legislative History}

Because the statutory language does not compel the majority interpretation and in fact offers adequate support for the minority view, the majority courts have relied primarily on the Code's legislative history. ${ }^{66}$ That history, though not dispositive, is in fact more supportive of the minority view.

\section{A. Enactment of the Code}

The legislative history of the Code makes very little useful reference either to exemptions in general or to paragraph (5) in particular. Contrary to the expectations of the Code's sponsors, ${ }^{67} \mathrm{ex}-$ emptions went virtually unmentioned in congressional floor debate, ${ }^{68}$ and the precise point at issue here was never conclusively addressed in any report or hearing. ${ }^{68}$ Consequently, the "legislative intent" behind paragraph (5) can only be inferred from an examination of the several legislative proposals and the few explicit, though inconclusive, comments and provisions pertaining to exemptions.

Two major legislative proposals on general bankruptcy law re-

6o See, e.g., In rè Smith, 640 F.2d 888, 891 (7th Cir. 1981) ("Our holding is based primarily on the legislative history of the Bankruptcy Reform Act of 1978."); In re LaFlamme, 14 Bankr. 21, 23 (Bankr. Ist Cir. 1981) ("should there be any question as to any ambiguity in the statute, particularly the phrase 'any property', the legislative history provides compelling evidence that the words 'any property' were purposely selected by the drafters"). The minority courts also have relied on legislative history. In re Smith, 10 Bankr. 792, 794 (C.D. IIl. 1980), rev'd, 640 F.2d 888 (7th Cir. 1981); LaFlamme v. Finance Am. Corp., 10 Bankr. 792, 794 (Bankr. D.R.I.), rev'd sub nom. In re LaFlamme, 14 Bankr. 21 (Bankr. 1st Cir. 1981).

${ }^{67}$ See Proposed New Federal Bankruptcy Act, 32 Bus. LAw. 247, 265-66 (1976). House subcommittee counsel and panel member Alan Parker predicted that "[e]xemptions will give the Congress a great deal of difficulty." Id. at 265.

os The two issues that attracted most congressional attention were the reorganization of the bankruptcy courts and the discharge of student educational loans. See Butler, supra note 2, at 563-64; Proposed New Federal Bankruptcy Act, supra note 67, at 265 (House subcommittee counsel's opinion that discharge of student loans had excited more public interest than any other aspect of bankruptcy reform). See also H.R. REP. No. 595, 95th Cong., 1st Sess. 132-62 (1977), reprinted in 1978 U.S. Code Cong. \& AD. NEws 5963, 6093123 [hereinafter cited as House REPORT]; 124 CoNG. REc. 1791-98 (1978) (debate on student loans); 123 CoNG. REc. 35,673-93 (1977) (debate on status of bankruptcy courts).

62 This absence of discussion or, apparently, interest, in itself suggests that the traditional approach to exemptions-that of the minority-may be the more plausible. On heavily debated topics, Congress's approach was in general conservative. See Aaron, supra note 2 , at 22-25, 28 (describing compromise on bankruptcy court reform and decision to retain existing law on discharge of student loans). If one assumes that this approach extended to areas that went unmentioned, the more conservative reading of paragraph (5) is supported, if not clearly vindicated. 
form were placed before Congress: a draft statute prepared by the Commission on the Bankruptcy Laws of the United States ("Commission Bill") ${ }^{70}$ and a competing draft prepared by the National Conference of Bankruptcy Judges ("Judges Bill"). ${ }^{71}$ A third proposal, addressing only exemptions and never formally proposed as a bill, was the Uniform Exemptions Act ("UEA"), prepared by the National Conference of Commissioners on Uniform State Laws. ${ }^{72}$ Each of these proposals adopted an exemption scheme of specified property, added some novel exemptions to the traditional categories, and either avoided or explicitly rejected the grubstake approach.

The Commission Bill enumerated seven general categories of exempt property, ${ }^{73}$ including a $\$ 5000$ homestead exemption. ${ }^{74}$ The Judges Bill contained a list of exempt property modeled on that of the Commission Bill, but differed in providing a homestead exemption of $\$ 6000,{ }^{75}$ an aggregate value limitation of $\$ 25,000$ for all exemptions ${ }^{78}$ and the option of taking state exemptions instead of federal exemptions. ${ }^{77}$ Both bills contained an "in lieu of homestead" exemption limited to a restrictive list of property, ${ }^{78}$ and

70 Congress created the Commission in 1970 to "study, analyze, evaluate, and recommend changes" to federal bankruptcy law. Pub. L. No. 91-354, § 1(b), 84 Stat. 468, 468 (1970). Three years later the Commission produced a report suggesting changes to the bankruptcy laws and including the draft statute hereinafter cited as "Commission Bill." REPORT of the Commission on the BankRuptcy Laws of the United States, H.R. Doc. No. 137 (2 vols.), 93d Cong., 1st Sess. (1973), reprinted in Colirer on Bankruptcy, supra note 2, app. 2 [hereinafter cited as Commission REPORT]. The Commission Bill was introduced in Congress in identical form as H.R. 10,792, 93d Cong., 1st Sess., 119 Cong. REc. 33,430 (1973); H.R. 31, 94th Cong., 1st Sess., 121 Cong. REc. 145 (1975); and S. 236, 94th Cong., 1st Sess., 121 CoNG. REc. 641 (1975).

${ }_{11}$ This bill was introduced in Congress in identical form as H.R. 16,643, 93d Cong., 2d Sess., 120 Cong. Rec. 30,970 (1974); H.R. 32, 94th Cong., 1st Sess., 121 Cong. Rec. 145 (1975); and S. 235, 94th Cong., 1st Sess., 121 Cong. Rec. 641 (1975). For a side-by-side comparison of the Commission Bill and the Judges Bill, see Bankruptcy Act Revision: Hearings on H.R. 31 and H.R. 32 Before the Subcomm. on Civil and Constitutional Rights of the House Comm. on the Judiciary, app. 1, 94th Cong., 1st \& 2d Sesss. (1975-76) [hereinafter cited as House Hearings].

${ }^{72}$ Uniform Exemptions Act (Nat'l Conf. of Comm'rs on Uniform State Laws 1976), reprinted in 13 U.L.A. 365 (1980) [hereinafter cited as UEA]. The UEA was amended in 1979 , but the amendments are not material to this comment; all references herein are to the 1976 version.

73 Commission Bill, supra note 70, § 4-503.

${ }^{34}$ Id. \& 4-503(b)(1).

78 Judges Bill, supra note 71, § 4-503(b).

${ }^{76}$ Id. § 4-503(a).

72 Id.

78 The Commission Bill provided:

(b) Homestead or Property in Lieu Thereof.- 
both provided for a liquid assets exemption of only $\$ 500 .^{29}$ The UEA enumerated five general categories of exempt property subdivided into numerous specific items. ${ }^{80} \mathrm{~A}$ debtor claiming the proposed $\$ 10,000$ homestead exemption could exempt $\$ 500$ in any liquid assets, while a debtor not claiming the homestead exemption was allowed $\$ 1500$ in any liquid assets to assist in the payment of rent. ${ }^{81}$ The comments accompanying the UEA specifically rejected the grubstake approach. ${ }^{82}$ None of these three proposals made any

(1) An individual debtor shall be allowed an exemption of property which he owned and was used at the date of the petition as a home for the debtor, his spouse, or a dependent or any or all of them. The aggregate value so allowable shall not exceed $\$ 5,000$ plus $\$ 500$ for each dependent of the debtor.

(2) If no property is allowed as exempt under paragraph (1) or if the property allowed has an aggregate value less than the maximum allowed under paragraph (1), an individual debtor shall be allowed additional exemptions of property of the kinds described in clauses (1) and (2) of subdivision (c) until the aggregate value of such additional property and property allowed as exempt under paragraph (1) of this subdivision equals the maximum value allowable under paragraph (1).

(c) Other Property.-The following property shall be allowed as exempt in addition to any property allowed as exempt under subsection (b):

(1) Livestock, wearing apparel, jewelry, household furnishings, tools of the trade or profession, and motor vehicles, to the aggregate value of not more $\$ 1,000$.

(2) A burial plot to the value of $\$ 2,500$.

Commission Bill, supra note 70, § 4-503.

Under the Judges Bill, a debtor who did not take the full homestead exemption was "allowed additional exemptions of property of the kinds described in clause (1) of subsection (e) of this section until the aggregate value of such additional property" reached the unused portion of the homestead exemption. Judges Bill, supra note 71, § 4-503(d). Subsection (e)(1) exempted "livestock, wearing apparel, jewelry, household furnishings, tools of trade or business, and motor vehicles." Id. § 4-503(e)(1).

70 Commission Bill, supra note 70, § 4-503(c)(3); Judges Bill, supra note 71, § 4503(e)(2).

so UEA, supra note 72, §§ 4-8.

8I Id. § 8(d). The comments to this section explained:

Subsection (d) recognizes the appropriateness of an additional allowance for an individual who claims no homestead exemption by allowing him a $\$ 1500$ exemption in liquid assets. The liquid assets so allowed may be applied to prepayment of rent but need not be so used in order to be available as an exemption.

${ }^{82}$ [T] ]he Act rejects the view that property of a delinquent debtor should be insulated from levy up to a certain value irrespective of its nature. The Uniform Exemptions Act, like Section 4-503 of the proposed Bankruptcy Act, introduced in the 93d and 94th Congresses, thus does not reflect the view that every debtor is entitled to a minimum grubstake for whatever purpose may please him. Rather the premise of the Act is that in order for a debtor's property to be protected against compulsory application to the payment of his indebtedness, it must be used, or be adaptable for use, in ways and for purposes deemed on balance to be preferable to such application. These ways and purposes have a perceived relation to the provision of shelter, clothing and other necessities of daily living in this country.

UEA, supra note 72, prefatory note. Academic sources cited in the UEA commentary that argue to the contrary are Joslin, supra note 19, at 362-75; Vukowich, supra note 16, at 829; 


\section{provision for the exemption of an unspecified category of "any property."}

The statements concerning exemptions presented in the congressional hearings ${ }^{\mathbf{B}}$ were more varied. The exemption schemes in the Commission and Judges Bills were described and defended by their drafters ${ }^{84}$ and enjoyed strong support. ${ }^{85}$ The grubstake approach was urged by representatives from the Brookings Institute, $^{88}$ the Consumer Law Center, ${ }^{87}$ and the Bureau of Consumer Protection of the Federal Trade Commission. ${ }^{88}$ Others argued for continuation of existing law. ${ }^{80}$ These statements generally were received without comment.

The first purely congressional product addressing exempted property was H.R. $6{ }^{90}$ a compromise bill based on the Commission Bill, the Judges Bill, and the UEA. ${ }^{91}$ Although H.R. 6 was followed by numerous successors, compromises, and reconciliations, ${ }^{92}$ it pro-

Note, supra note 19, at 671-83; and Comment, supra note 19, at 1507-14. The drafters were concerned in part over the expense of a complete property appraisal in every bankruptcy. UEA, supra note $72, \S 8$ comment 2.

${ }_{83}$ In 1975 , both houses of Congress began hearings on the Commission, Judges, and UEA proposals. The most extensive took place before a House subcommittee chaired by Representative Don Edwards. House Hearings, supra note 71. The subcommittee produced over 2500 pages of hearing records, $i d$., a line-by-line comparison of the Commission and Judges Bills, id. at app. 1 , and a compilation of all bankruptcy legislation prior to 1975 , id. at supp. app. pts. 1-2. See also The Bankruptcy Reform Act: Hearings on S. 235 and S. 236 Before the Subcomm. on Improvements in Judicial Machinery of the Sen. Comm. on the Judiciary, 94th Cong., 1st Sess. (1975) [hereinafter cited as Senate Hearings].

Bt See, e.g., House Hearings, supra note 71, at 184-85, 192-93, 284-86, 359, 1282, 1305; Senate Hearings, supra note 83, at 24-25, 29, 36, 41, 61-62, 96-97, 120-21.

${ }^{85}$ See, e.g., House Hearings, supra note 71, at 898, 909, 977-78, 1025, 1369, 1394, 1658, 1663-64, 2094, 2117-18; Senate Hearings, supra note 83, at 127-28, 135-36, 145-46, 477, 483, $489,537$.

${ }^{86}$ See House Hearings, supra note 71, at 369; Senate Hearings, supra note 83, at 877. The Institute was represented by coauthors David Stanley and Marjorie Girth. See supra note 19.

${ }^{87}$ See House Hearings, supra note 71, at 937-41, 945-46; Senate Hearings, supra note 83 , at 309-11, 323, 333-39.

${ }^{88}$ See House Hearings, supra note 71 , at 762-64, 787-88, 864-65, 884-85.

so See, e.g., House Hearings, supra note 71, at 1622, 1674; Senate Hearings, supra note 83, at $433,630-34,665-66,814-21$.

${ }^{20}$ H.R. 6, 95th Cong., 1st Sess., 123 Cong. Rec. 125 (1977).

${ }^{91}$ The production of the House compromise bill is described in detail by Klee, supra note 2, at 279-81. Klee was one of two draftsmen of the bill. See Kennedy, supra note 4, at 675 n.41. The deliberations and memoranda of the congressional committees involved in the enactment of the Code are not available for study other than as presented in the official legislative history. Letter from Representative Peter Rodino (Dec. 1, 1981) (on file with The University of Chicago Law Review).

${ }^{82}$ H.R. 6 was followed by two versions having essentially the same exemption provisions. H.R. 7330, 95th Cong., 1st Sess., 123 Cong. Rec. 15,941 (1977); H.R. 8200, 95th Cong., 
vided for exemptions identical to those in the Code as enacted, except that in the Code the dollar amounts per exemption category were reduced,"93 a "family heirlooms" category was struck, ${ }^{94}$ and the state option to deny use of the federal exemptions was added. ${ }^{95}$

The property exemptions of H.R. 6 were also virtually identical to those of the UEA, except that the UEA's "in lieu of homestead" provision, which concerned liquid assets only, was replaced by what is now paragraph (5). The sole congressional explanation for this change is in the report accompanying the final House version of the bill. In a section-by-section analysis, the report, noting that the exemptions were "derived in large part from the Uniform Exemptions Act," states that "paragraph (5) permits the exemption of $\$ 500$, plus any unused amount of the homestead exemption, in any property, in order not to discriminate against the nonhomeowner." Bs Because paragraph (5) survived without significant change, ${ }^{97}$ the report is relevant to its interpretation; no other direct reference to paragraph (5) exists in the Code's voluminous legislative history.

\section{B. The Arguments}

This slim basis of pertinent legislative history has given rise to three arguments by the majority-view courts. These rest on the

1st Sess., 123 CoNG. REC. 35,644 (1977). H.R. 8200 was accompanied by an extensive subcommittee report and section-by-section analysis. House REPORT, supra note 68 . The Senate prepared a substantially different bill, S. 2266, 95th Cong., 1st Sess., 123 Cong. Rec. 36,091 (1977), and a report, S. REP. No. 989, 95th Cong., 2d Sess. (1978), reprinted in 1978 U.S. Code Cong. \& AD. News 5787 [hereinafter cited as Senate Report].

In 1978 a compromise bill, based primarily on H.R. 8200, was reported to both houses in coordinated statements by its sponsors. 124 CoNG. REc. 32,392 (1978) (statement of Rep. Edwards), reprinted in 1978 U.S. Code Cong. \& AD. News 6436; 124 Cong. Rzc. 33,990 (1978) (statement of Sen. DeConcini), reprinted in 1978 U.S. Code Cong. \& AD. News 6505. The bill was enacted into law on October 6, 1978. 124 Cong. Rec. 34, 143-45 (1978).

's Compare H.R. 6, 95th Cong., 1st Sess., 123 CoNG. Rec. 125 (1977) with 11 U.S.C. \& 522(d) (Supp. IV 1980). The amounts corresponding to the Code paragraphs were: paragraph (1), $\$ 10,000$ proposed $/ \$ 7500$ enacted; (2), $\$ 1500 / \$ 1200 ;(3), \$ 300 / \$ 200 ;(4), \$ 750 / \$ 500$; (5), $\$ 500 / \$ 400 ;(6), \$ 1000 / \$ 750 ;(8), \$ 5000 / \$ 4000$; (11)(D), no limit $/ \$ 7500$. The figures proposed in H.R. 6 correspond in every instance to those in the UEA.

94 H.R. 7330 and H.R. 8200 eliminated the heirloom provision of H.R. 6.

is 124 Cong. Rec. 32,398 (1978) (statement of Rep. Edwards), reprinted in 1978 U.S. Code Cong. \& AD. News 6436, 6452-53; 11 U.S.C. § 522(b) (Supp. IV 1980).

${ }^{36}$ House Report, supra note 68, at 361, reprinted in 1978 U.S. Code Cong. \& AD. NEws 5963, 6317.

${ }^{97}$ The sole changes in paragraph (5) between the House report and the enactment of the Code consisted of a reduction of the exemption amounts from $\$ 10,000$ and $\$ 500$ to $\$ 7500$ and $\$ 400$, respectively. See supra note 93 . 
House report's statement concerning discrimination against nonhomeowners, on the unenacted legislative proposals, and on Congress's oft-stated concern for giving debtors a "fresh start."

1. Discrimination. The majority-view courts frequently have noted that paragraph (5) was designed specifically to prevent discrimination against the nonhomeowner. ${ }^{98}$ The majority approach provides a superficially appealing means of preventing such discrimination: debtors with and without homesteads are permitted the same $\$ 7900$ grubstake; every debtor thus has access to the same total dollar value of property, if not to the same forms of property. ${ }^{98}$ However, the minority approach also prevents discrimination against homeowners: a debtor not exercising the homestead exemption can exempt larger dollar amounts of those forms of

${ }^{23}$ E.g., In re Smith, 640 F.2d 888, 891 \& n.17 (7th Cir. 1981); In re LaFlamme, 14 Bankr. 21, 24 (Bankr. 1st Cir. 1981); Leech v. Nichols, 4 Bankr. 711, 716 (Bankr. E.D. Mich. 1980); In re Upright, 1 Bankr. 694, 702 (Bankr. N.D.N.Y. 1979).

- The general exemption was intended to ensure that there was no discrimination between homeowners and non-homeowners .... By permitting non-homeowners (or homeowners with property valued under $\$ 7500$ ) to exempt the unused portion of the homestead exemption, plus $\$ 400$, Congress in effect gave all debtors potentially the same $\$ 7,900$ stake. . . . [T] $]$ he Code as enacted permits the use of "any property." . . . In view of Congress' goal of providing a meaningful fresh start for debtors, it makes no sense to limit the type of property that may be applied to the general exemption without a clear statement of Congressional intent to do so.

In re Smith, 640 F.2d 888, 891 (7th Cir. 1981) (footnotes omitted).

This argument, though appealing, proves too much; complete adherence to it would have required Congress to provide that the unused portion of every exemption apply to "any property," and there is of course no such provision. If the minority view's limitation of the homestead overflow "makes no sense," it was equally unreasonable for Congress to disregard completely the potential overflows from the aggregate value exemptions for a motor vehicle $(\$ 1200)$, jewelry $(\$ 500)$, tools of trade $(\$ 750)$, life insurance $(\$ 4000)$, and personal injury awards ( $\$ 7500)$, which together total $\$ 13,950$. See text of section 522(d), supra note 5. Congressional intent to avoid discrimination against nonhomeowners is clear, but under the majority interpretation of paragraph (5), that intent can only be achieved by further discrimination against debtors not owning the full amount of each of the other above-listed types of property. Although the minority view also does not eliminate the apparently inequitable distinction between the homestead exemption and all other exemptions in section 522(d), it does minimize the inequitable effect of that distinction by restricting all debtors to the specified exemptions, thereby reducing the "spread" of potentially exemptable property.

Several commentators have noted that the Code, and indeed virtually all existing approaches to property exemption in bankruptcy, are discriminatory per se in that those debtors with property are favored over those without. See, e.g., Donnelly, The New (Proposed?) Bankruptcy Act: The Development of Its Structural Provisions and their Impact on the Interests of Consumer-Debtors, 18 SANTA ClARA L. Rev. 291, 331-32 (1978); Plumb, supra note 19 , at $96 \&$ n. 575; Vukowich, supra note 4 , at 770-71. This feature is not inconsistent with the traditional rationale behind property exemptions, nor does it provide any apparent reason for abandoning the "preferred" property concept in favor of the grubstake approach. 
property specified as exempt in subsection $522(\mathrm{~d})$ than can a debtor claiming any part of the homestead exemption. Again, each category of debtor has access to the same total dollar value of property, if not to identical forms of property. ${ }^{100}$

Furthermore, Congress expressly permitted debtors to continue the pre-Code practice of exchanging nonexempt for exempt property on the "eve of bankruptcy."101 This opportunity virtually eliminates the discrimination among owners of differing types of property that is implicit in any scheme of specific exemptions and in effect serves to encourage debtor acquisition of preferred property. ${ }^{102}$ Congressional notice and approval of this practice not only verifies that Congress intended to avoid discrimination to the extent possible, but suggests that Congress envisioned achieving nondiscrimination within a scheme of specified exemptions and by means of eve-of-bankruptcy exchanges where necessary.

Thus the majority and minority approaches both achieve the congressional goal of nondiscrimination. The majority approach, however, does so by extending exempt status to property not generally preferred or listed in the Code. This is inconsistent both with the congressional intent implicit in the enumeration of preferred property exemptions ${ }^{103}$ and with congressional endorsement of eve-of-bankruptcy acquisitions of preferred property. The minority view, in contrast, is consistent with the implicit congressional intent to provide special protection to certain preferred debtor property and encourages exchanges on the eve of bankruptcy.

2. The Proposals Not Enacted. Several courts have argued that Congress's failure to enact the Commission, Judges, or UEA proposals corresponding to paragraph (5), coupled with its adoption of an apparently different scheme, constituted a rejection of those proposals and, consequently, a rejection of the minority approach. ${ }^{104} \mathrm{~A}$ number of considerations, however, indicate that the

100 It should be noted that neither the majority nor the minority approach requires a debtor with a homestead to use the homestead exemption rather than using paragraph (5) to exempt other forms of property of equal value.

101 See House RePorT, supra note 68, at 361, reprinted in 1978 U.S. Cone CoNG. \& AD. News 5963, 6317.

${ }^{102}$ See supra note 47.

103 See supra notes 25-32 and accompanying text.

104 See, e.g., In re Smith, 640 F.2d 888, 893 (7th Cir. 1981) (footnote omitted):

We find it significant, however, that Congress rejected [the UEA] formula-and, as noted earlier, the specific limitations of the general exemption in the Commission's draft bill-and substituted instead the broad phrase "any property." If Congress had 
significance of this "rejection" has been misinterpreted.

a. The UEA. Congress explicitly noted that the Code exemptions were based in large part on the UEA and that it wanted to avoid discrimination against nonhomeowners. ${ }^{105}$ However, the UEA did discriminate against nonhomeowners: it allowed them only a $\$ 1000$ increase in the liquid assets exemption as against a loss of $\$ 10,000$ in the homestead exemption. ${ }^{108}$ It therefore was necessary to modify or replace the UEA's "in lieu of homestead" provision. Even if modified to allow identical total exemptions for homeowners and nonhomeowners, however, the provision still would have provided only an all-or-nothing choice between the exemption of a homestead of indeterminate value and a fixed dollar amount of liquid assets. ${ }^{107}$ These considerations called for an outright replacement of the UEA provision. In any event, because the provision itself directly adopted neither the majority nor the minority approach, its rejection can cast little light on the present debate.

The other major congressional modifications to the UEA proposal, however, are revealing. Congress altered the dollar amount of all the UEA exemptions included in the Code. Under the majority approach, these alterations are oddly asymmetric: the Code shows approximately a $500 \%$ increase in the value of the "general" exemption, but a $20-60 \%$ decrease in every other exemption. ${ }^{108}$

intended to limit the property usable under the general exemption, it certainly had examples of how it could have done so.

See also Chrystler v. Geresy (In re Brock), 10 Bankr. 67, 70 (Bankr. W.D. Mich. 1981).

${ }^{105}$ See supra note 96 and accompanying text.

${ }^{108}$ See supra note 81 and accompanying text.

107 The original UEA scheme provided homeowners a homestead exemption of $\$ 10,000$ and a liquid assets exemption of $\$ 500$, while nonhomeowners were granted a liquid assets exemption of $\$ 1500$ only. UEA, supra note $72, \S \S 4(\mathrm{a}), 8(\mathrm{~d})$. Equalizing the liquid assets exemption for the two classes of debtors, even at the amount of $\$ 10,000$, would not have solved the problem of a debtor with a homestead worth less than the total allowable liquid assets exemption, nor would it have permitted either homestead or liquid asset exemption overflow to be reassigned to other forms of property. By restricting the debtor to a choice of either the homestead or the larger liquid asset exemption, the UEA "in lieu of homestead" provision would produce debtors with unequal total exemptions.

${ }^{108}$ These percentages were determined as follows:

\begin{tabular}{lllll} 
Exemption & UEA $\S /$ amount & & Code $/$ amount & \% change \\
\cline { 2 - 2 } homestead & $4 \quad \$ 10,000$ & & $522(\mathrm{~d})(1) / \$ 7500$ & $-25 \%$ \\
motor vehicle & $8(\mathrm{c}) / \$ 1500$ & & $522(\mathrm{~d})(2) / \$ 1200$ & $-20 \%$ \\
household goods & $8(\mathrm{a}) / \$ 500$ per item & & $522(\mathrm{~d})(3) / \$ 200$ per item & $-60 \%$ \\
jewelry & $8(\mathrm{~b}) / \$ 750$ & & $522(\mathrm{~d})(4) / \$ 500$ & $-33 \%$
\end{tabular}


Given the marked and intended similarity of the Code and UEA exemption provisions, it is difficult to explain such a large deviation both from the UEA scheme and from Congress's consistent reductions of the dollar values of the UEA exemptions. ${ }^{109}$ It seems unlikely that Congress intended to increase the cash exemption for those not claiming a homestead exemption to more than five times the most generous figure proposed, while reducing every other exemption allowance. ${ }^{110}$ Under the minority view, Congress's modifi-

general

$/ \$ 1500 \mathrm{w} / \mathrm{o}$

tools of trade

life insurance

personal injury $8(c) / \$ 1000$

$$
\begin{aligned}
& 8(d) / \$ 500 \text { "liquid assets" } \\
& \text { w/home }
\end{aligned}
$$

$7 \quad 1 \$ 1500$

6 /necessary for support
$522(d)(5) / \$ 400$ "any property"
w/home
$-20 \%$
$/ \$ 7900 \mathrm{w} / \mathrm{o}$
$+527 \%$
$-25 \%$
$522(d)(6) / \$ 750$
indeterminate
$522(d)(8) / \$ 4000$ less debt
$522(d)(11) / \$ 7500$

These figures demonstrate that the Code's "general" exemption was not simply increased to counterbalance the decreases in all other exemptions from the UEA amounts. The paragraph (5) figures originally proposed were derived from the UEA cash and homestead exemption amounts for homeowners (there being no need to adopt the UEA cash exemption for nonhomeowners given the intent to equalize the two classes of debtor) of $\$ 500$ and $\$ 10,000$ respectively, which were reduced to $\$ 400$ and $\$ 7500$ respectively. All other fixed value exemptions in the Code were similarly reduced.

102 It is possible that the House subcommittee may have been aware of the precise extent of the Code's deviation from the UEA and earlier proposals, while Congress as a whole may not have been. The aims and intentions of a congressional committee, however, are not to be equated with congressional intent, SEC v. Sloan, 436 U.S. 103, 119-21 (1978), and it would appear that this restrictive view extends to the staff of a subcommittee and includes the drafters of a piece of legislation. The question is of some importance, because at least one of the draftsmen of the Code, Kenneth Klee, agrees with the majority interpretation of paragraph (5). See Cohen \& Klee, Caveat Creditor: The Consumer Debtor Under the Bankruptcy Code, 58 N.C.L. REv. 681, 693 (1980).

Even apart from the Sloan holding, Mr. Klee's views are not entitled to great weight, for they were offered ex post. See Goolsby v. Blumenthal, 581 F.2d 455, 460 (5th Cir. 1978), aff'd per curiam in relevant part, 590 F.2d 1369 (5th Cir.) (en banc), cert. denied, 444 U.S. 970 (1979); Posner, Economics, Politics, and the Reading of Statutes and the Constitution, 49 U. CH. L. RBv. 263, 275 (1982).

110 As noted supra note 13 , the minority view can be interpreted as eliminating any cash or general exemption. Even under such a restrictive interpretation, however, there still is far less deviation from the consistent treatment of UEA exemption allowances than under the majority view: a cash allowance of zero differs from the largest UEA cash exemption figure of $\$ 1500$ by $\$ 1500$, while a cash allowance of $\$ 7900$ under the majority view differs from that same standard by $\$ 6400$. Still, elimination of the cash exemption is a qualitative as well as quantitative change. Therefore, the alternative minority reading of paragraph (5), in which a cash or general exemption of $\$ 400$ is permitted but the homestead overflow of up to $\$ 7500$ is restricted to the exemption of property specified in section $522(\mathrm{~d})$, seems more plausible. Under this reading, the cash exemption is reduced by $20 \%$ from the $\$ 500$ permitted homeowners in the UEA and thus is entirely consistent with the general range of reductions of the UEA allowances. 
cations to the UEA exemption allowances are far more consistent.

b. The Commission and Judges Bills. The "in lieu of homestead" provisions of the Commission and Judges Bills adhered to the minority approach, ${ }^{111}$ and Congress's failure to use either is less easily explained than its abandonment of the UEA provision. It is probable that once it chose the UEA as a framework, Congress simply disregarded the exemption provisions of the Commission and Judges Bills altogether. Assuming that Congress did analyze those other bills carefully, however, their "in lieu of homestead" provisions were poorly designed for insertion into the UEA scheme. The Commission and Judges Bills applied the unused portion of the homestead exemption to categories of exempted property that were organized differently than those of the UEA and that generally had aggregate value limitations, as opposed to the per-item or no value limitations placed on the same approximate categories under the UEA. ${ }^{112}$ More significantly, the Commission and Judges Bills restricted the homestead overflow to a limited number of specified exemptions rather than to all specified exemptions as urged here. ${ }^{113}$ The congressional.decision to apply the "in lieu of homestead" provision to "any property" thus would seem merely to extend the restrictive language of the Commission and Judges Bills to all exempted property, and not to any property whatever. That the provision was made broader does not mean it was made as broad as possible.

In sum, it seems that the decision to adopt a newly drafted "in lieu of homestead" provision constituted a rejection only of the particular limitations of the discriminatory UEA provisions and the improperly tailored provisions of the Commission and Judges Bills, and not of the minority view itself. It must be remembered that Congress did not simply enact an exemption provision containing a single dollar figure and no other specification of property, although such a provision would have been far easier to draft than

111 See supra note 78 and accompanying text.

112 See Commission Bill, supra note 70, § 4-503(b)(2) (allowing the homestead overflow to be applied to the aggregate value of "[l]ivestock, wearing apparel, jewelry, household furnishings, tools of the trade or profession, and motor vehicles" and a "burial plot"); Judges Bill, supra note 71, § 4-503(d) (allowing the homestead overflow to the applied to the aggregate value of "[l]ivestock, wearing apparel, jewelry, household furnishings, tools of trade or profession, and motor vehicles"); UEA, supra note 72, § 5(1) (burial plot exempt without limit), \& 8(a)(1)-(2) (furnishings, appliances, wearing apparel, animals, and so forth, exempt to $\$ 500$ per item).

11 Compare supra note 12 and accompanying text with supra note 78. 
the detailed exemption scheme adopted.114 Furthermore, the explicit mention by Congress that the Code exemption provisions were based "in large part" on the UEA ${ }^{115}$ demonstrates the legislative intent to continue with the tradition of specified property exemptions embodied in that proposal. Finally, the fact that the Commission and Judges Bills essentially adopted the minority approach indicates that this was the prevailing view during the fouryear period when the Code was developed. It seems unlikely that Congress would reject this longstanding approach without a word.

3. The "Fresh Start." The significance of the debtor's "fresh start" to the formulation of the Code can hardly be overstated. It can, however, be misunderstood. The majority-view courts contend that the frequently repeated congressional concern with providing a meaningful fresh start for debtors ${ }^{116}$ directly supports their liberal reading of section $522(\mathrm{~d}) .{ }^{117}$ This view has attracted some academic commentary in its favor. ${ }^{118}$ Any connection between the debtor's fresh start and property exemptions, however, is a far from established concept ${ }^{119}$ that is equally supportive of the minor-

124 Some of the commentators who have urged a single dollar figure, however, have recognized that it would be no easy matter to pick the precise figure. See, e.g., Countryman, supra note 19, at 746-48; Kennedy, Limitations, supra note 14, at 451-52; Comment, supra note 19 , at $1507-10$.

${ }^{218}$ Houss Report, supra note 68, at 361, reprinted in 1978 U.S. Code Cong. \& AD. News 5963, 6317.

126 See, e.g., Commission ReporT, supra note 70, at 78-80; Houss REPORT, supra note 68, at 116-18, 126-27, reprinted in 1978 U.S. CoDE CoNG. \& AD. News 5963, 6076-79, 608788; 124 Cong. REC. 28,258, 28,260, 32,392, 32,418 (1978); id. S17,432 (daily ed. Oct. 6, 1978) (remarks of Rep. Butler); 123 CoNG. REc. 35,436, 35,444-46, 35,451-53, 35,672 (1977).

${ }^{117}$ In re Smith, 640 F.2d 888, 891 (7th Cir. 1981) ("In view of Congress' goal of providing a meaningful fresh start for debtors, it makes no sense to limit the type of property that may be applied to the general exemption without a clear statement of Congressional intent to do so."); In re LaFlamme, 14 Bankr. 21, 24 (Bankr. 1st Cir. 1981) ("Congress did, in fact, intend such a general exemption in order to better insure [sic] the debtor's fresh start ... ."); Leech v. Nichols, 4 Bankr. 711, 717 (Bankr. E.D. Mich. 1980) (the minority approach "unnecessarily limits the intent of Congress to preserve the property available to a debtor with which a fresh start can be made").

11 See, e.g., Comment, Protection of a Debtor's "Fresh Start" Under the New Bankruptcy Code, 29 CATH. U.L. Rev. 843, 850-59 (1980).

110 See Kennedy, Reflections, supra note 14, at 447-50. Professor Kennedy notes that the Supreme Court bankruptcy exemption cases of Lines v. Frederick, 400 U.S. 18 (1970), and Kokoszka v. Belford, 417 U.S. 642 (1974), "illustrate the extent to which the 'fresh start' policy has become a dominant factor not only in construing the discharge provisions of the Bankruptcy Act but even in determining the scope of the property of the estate of an individual debtor that is to be administered in bankruptcy." Id. at 450 .

However, Kokoszka-the Court's most recent pronouncement on debtor exemptions-held an income tax refund to be property "sufficiently rooted in the prebankruptcy past" to be nonexempt and not related to the "future wages" required for a fresh start. 417 
ity view.

Traditionally, the fresh start related solely to the debtor's discharge from existing debt. ${ }^{120}$ Although the Code's legislative history contains statements in which the fresh start and exemptions are discussed together, those references generally concern the preservation of a meaningful discharge by invalidating various creditor encumbrances on exempted property. ${ }^{121}$ The focus is thus not on the exempted property itself, but rather on the completeness of the discharge. The "fresh start," though important to the Code, is largely unrelated to interpretation of paragraph (5).

Still, it is apparent that the likelihood of an effective fresh

U.S. at 647-48. Thus it would appear that the connection between exemptions and the "fresh start" perceived by Professor Kennedy in 1974 hardly requires a liberal construction of those exemptions.

${ }^{220}$ For indications of congressional recognition of the primary importance of the discharge to a fresh start, see Commission Report, supra note 70, at 80; Houss REPorT, supra note 68, at 128-34, reprinted in 1978 U.S. Code ConG. \& AD. News. 5963, 6089-95; 124 CoNG. REc. 32,392 (1978). For commentary maintaining that the primary importance of the discharge was maintained throughout the Code, see Cohen \& Klee, supra note 109, at 68183, 721; Rendleman, The Bankruptcy Discharge: Toward a Fresher Start, 58 N.C.L. REv. 723, 723-24 (1980); Shonor, A New Deal for Secured Creditors in Bankruptcy, 28 EмоRY L.J. 588, 644-46 (1979). Concerning the primary importance of the discharge in general, see Joslin, The Philosophy of Bankruptcy-A Re-Examination, 17 U. FLA. L. RBv. 189, 194-95 (1964); Kennedy, Reflections, supra note 14, at 434-36; Shuchman, supra note 45, at 420. For an honorable mention given to exemptions as second only to the discharge in importance to debtors, see Countryman, supra note 19, at 678 .

In the better known paeans to the fresh start, the courts have shown predominant concern with discharge. Justice Sutherland is frequently cited:

One of the primary purposes of the bankruptcy act is to "relieve the honest debtor from the weight of oppressive indebtedness and permit him to start afresh free from the obligations and responsibilities consequent upon business misfortunes." . . This purpose of the act has been again and again emphasized by the courts as being of public as well as private interest, in that it gives to the honest but unfortunate debtor who surrenders for distribution the property which he owns at the time of bankruptcy, a new opportunity in life and a clear field for future effort, unhampered by the pressure and discouragement of preexisting debt.

Local Loan Co. v. Hunt, 292 U.S. 234, 244 (1934) (emphasis in original) (citation omitted). Courts administering the Code have offered similar sentiments. See, e.g., Steinberg v. Reagan, 13 Bankr. 588, 588 (Bankr. E.D. Tenn. 1981). But see Head v. Home Credit Co., 4 Bankr. 521, 524 (Bankr. D. Tenn. 1980) ("The purpose of allowing exemptions is to provide the debtor with sufficient property to support himself and his dependents and to make a fresh start.").

${ }^{121}$ See, e.g., Commission REPORT, supra note 70, at 78-80; House REPORT, supra note 92, at 116-18, 126-27, reprinted in 1978 U.S. CoDE CoNG. \& AD. News 5963, 6077-78, 608788; 124 Cong. Rec. 32,392, 32,418 (1978); id. S17,432 (daily ed. Oct. 6, 1978); 123 Cong. Rzc. $35,451-53,35,672$ (1977).

The sole use of the words "fresh start" in the Code appears in an oddly inconsequential section in which Congress indicated that it wished to ensure the debtor a fresh start in cases ancillary to foreign proceedings. 11 U.S.C. $\S 304$ (c)(6) (Supp. IV 1980). 
start is affected at least in part by the debtor's retention of property, particularly as regards items of high replacement cost that are necessary for continued productive existence. Confiscation of such property inevitably would require repurchase, and therefore resumption of indebtedness. The majority and minority interpretations of paragraph (5) provide equal fresh starts by quantitative measure. ${ }^{122}$ The minority approach, however, is more supportive of the fresh start in qualitative terms. By adhering strictly to the traditional forms of preferred property, it assures that those items exempted will be directly relevant to continued productive existence. ${ }^{123}$

\section{Practical Considerations}

Judicial and academic discussions of paragraph (5) have been surprisingly free of any open assessment of the practical consequences of the majority and minority views, perhaps because the Code was so recently enacted that data concerning its impact on bankruptcy administration is still limited. ${ }^{124}$ In the two and onehalf years that the Code has been in operation, however, the acceleration of certain broad statistical trends that began much earlier may be discerned. Under former law, the number of personal bankruptcies increased from a post-World War II low of 10,196 in 1946 to a pre-Code high of 254,484 in $1975 .{ }^{125}$ Most of this increase

122 See supra notes 99-100 and accompanying text.

125 See supra note 26 and accompanying text.

124 It is equally possible that the courts are simply avoiding any appearance of "judicial legislation" in this unsettled area of new law. In In re Ancira, 5 Bankr. 673 (Bankr. N.D. Cal. 1980), a majority-view court allowed the "stacking" of state and federal exemptions by joint debtors, thus permitting a homestead exemption of $\$ 37,500$. Id. at 673,675 . The court noted that:

Apparently the trustee believes that the stacking of the two exemptions is unjust and a windfall to debtors. What is "unjust" or a "windfall" is a value judgment, however. Although to some, certain benefits may be unwarranted largess, to others, the same relief may be an essential element of a "fresh start." Obviously, Congress intended to grant extensive benefits to debtors through the new Code. In the absence of a clear indication from the Congress as to the limits on these benefits, I do not believe the courts can restrict exemptions, as requested by the trustee, on the basis of their own concepts of fairness and propriety.

Id. at 675 .

Judge Hughes, however, has stated flatly that the majority interpretation of paragraph (5) entails the possible substitution of "less favored property" for "highly favored," the election of federal rather than state exemptions "in the majority of cases," and the substantial curtailment of cases in which assets are available to creditors. Hughes, supra note 2, at 1031-32.

128 Countryman, supra note 14, at 231. 
has been attributed to the expansion of consumer credit, ${ }^{126}$ a factor unchanged since enactment of the Code. Nevertheless, the number of bankruptcies filed in 1979 (the last pre-Code year) approximated the decade-long average of some 200,000, while in both 1980 and 1981 over 400,000 personal bankruptcies were filed: a $100 \%$ increase apparently attributable in large part to the Code. ${ }^{\mathbf{1 2 7}}$

Concerning the assets of those individuals declaring bankruptcy, one relatively limited study made in 1959 determined that the average debtor retained exempt assets worth $\$ 953$, with only a small percentage of estates providing any assets for distribution to creditors. ${ }^{128}$ A more extensive study completed in 1971 found that the average exemptions claimed totalled $\$ 500$, with only 16 percent of debtor estates providing assets for creditors. ${ }^{128} \mathrm{~A}$ study conducted since the Code's enactment found average exemptions to be $\$ 7036$, with only $5.3 \%$ of debtors being able to fully repay debts from nonexempt assets. ${ }^{130}$

These figures indicate that steadily increasing numbers of debtors are filing for personal bankruptcy and, since the Code's enactment, are doing so under exemption provisions that exceed their average assets. ${ }^{131}$ Under either the majority or minority inter-

${ }^{128}$ Commission Report, supra note 70, at 49-51; D. Stanley \& M. GirTH, supra note 19, at 3; Note, supra note 19, at 663.

127 BANKRUPTCY STUDY, supra note 28, at 84; Evans, supra note 4, at 1259. Although enacted in 1978, the Code did not go into effect until October 1, 1979, and thus the first meaningful annual statistics measuring its impact are those for 1980. See supra note 1 .

128 Comment, supra note 19, at 1504-07.

129 D. Stanley \& M. GiRTh, supra note 19 , at $58,81-84,87-88$. This study notes that the actual as opposed to the claimed value of exemptions is difficult to determine given the varying state exemption "start points" and property categories, particularly those that include those forms of property exempted without limit or exempted under a per item limit. This problem of the data is also noted in House Hearings, supra note 71, at 768-69.

130 BANKRUPTCy STUDY, supra note 28 , at 69,78 . The study also determined that a second sample of debtors, for which no debt repayment percentage was calculated, averaged exemptions totalling $\$ 7885$. Id. exhibit $3 \mathrm{~A}-1$, at 78 . The study concluded that 15 to $30 \%$ of consumer debtors could repay all debts out of future income. Id. at 72. A second volume of the study, specifically addressing debtor characteristics and exemptions, was not prepared in time for inclusion in this comment. See Credit Research Center, Monograph No. 24, Consumer Bankruptcy STUdY (vol. 2) (1982).

${ }^{132}$ It has long been recognized that most consumer bankruptcies are "no asset" proceedings in which creditors receive nothing. See, e.g., Douglas, Wage Earner Bankruptcies-State v. Federal Control, 42 Y ALE L.J. 591, 626 (1933); Kennedy, Foreword to A Tribute to Stefan A. Riesenfeld: A Discussion of the Proposed Bankruptcy Acts, 63 CALr. L. REv. 1427, 1432 \& n.23 (1975); Comment, supra note 19, at 1504. In a study conducted by then-Professor William O. Douglas in 1931 and 1932, 408 bankrupts were found to have assets totalling $\$ 590,542$ and debts totalling $\$ 6,616,365$. Douglas, supra, at $593 \mathrm{n} .8,626$. More recent studies show a similar disparity. See, e.g., BANKRUPTCY STUDY, supra note 28, 
pretation of paragraph (5), the Code's exemption scheme thus allows virtually complete retention of assets by the average debtor. ${ }^{132}$ Although this general result of debtor discharge without a corresponding liquidation of assets appears to be unfair to creditors, ${ }^{15 s}$ it has been noted that the costs of such a policy are borne indirectly by society at large. ${ }^{134}$ It is therefore entirely appropriate for Congress to determine the particular level of personal wealth at which the benefit of discharge will be extended to a debtor. ${ }^{135}$

These practical considerations place the controversy over paragraph (5) into its proper and limited perspective, but do not divest it of importance. If Congress has determined a given level of wealth below which debtors will have virtually complete property exemption in bankruptcy, the proper resolution of the grubstake and specified exemptions dispute is necessary to determine precisely what property is included below that level. Although most debtors will be unaffected by the resolution of the paragraph (5) controversy, it appears highly unlikely that Congress intended those few debtors possessing valuable assets not specifically exempted by the generous provisions of the Code to retain them at the expense of creditors and, ultimately, of all society. ${ }^{136}$ The un-

exhibit 3A-1, at 78; D. STANLEY \& M. GIRTH, supra note 19, at 57-58. In the artificial sense that cancellation of indebtedness is income, some debtors arguably are achieving the chimerical "instant affluence" that concerned the Senate when it unsuccessfully proposed to eliminate federal exemptions from the Code. See Senate RBPort, supra note 92, at 6, reprinted in 1978 U.S. Code Cong. \& AD. News 5787, 5792. That proposal has been reintroduced before the current Congress. See supra note 4 .

132 Because all three of the studies cited supra notes $128-30$ found an average debtor asset figure below $\$ 8000$, and because the Code's aggregate exemptions total $\$ 13,950$ without including either the per item value exemptions or the potential $\$ 7900$ aggregate of paragraph (5), see supra note 99 , it is clear that the latter exemption will, on the average, be of no concern to the debtor.

${ }^{183}$ Congressmen frequently mentioned that the Code was intended to provide a balanced treatment to debtors and creditors. See, e.g., House RkPorT, supra note 68, at 4-5, reprinted in 1978 U.S. CoDr CoNG. \& AD. NEws 5963, 5965-66; SENATE REPORT, supra note 92, at 5-6, reprinted in 1978 U.S. Code Cong. \& AD. NEws 5787, 5791-92; 124 Cong. Rac. 35,452 (1977); id. at 32,418 (1978); id. S17,432 (daily ed. Oct. 6, 1978). Some commentators have suggested, however, that the Code is particularly detrimental to creditors. See, e.g., Williams, supra note 2 , at 16.

134 See supra notes 27-29 and accompanying text.

1ss For a discussion of the policy implications of this determination, see generally Vukowich, supra note 23 , at 781-88.

136 See supra notes $27-29$ and accompanying text.

Chapter 13 of the Code, 11 U.S.C. $\$ \$ 1301-1330$ (Supp. IV 1980) provides for debt adjustment rather than liquidation and thus allows complete retention of property by debtors opting for that form of bankruptcy. This theoretically distinctive characteristic of debt adjustment proceedings is undercut by the practical effect of exemptions extended to debtors 
usual debtors noted earlier, ${ }^{137}$ owning large amounts of cash, business inventory, and investment real estate, can hardly have been anticipated as personal bankrupts by Congress, much less as bankrupts entitled to exempt such assets. Nevertheless, the exemption of such assets is the inevitable consequence of the majority grubstake interpretation of paragraph (5).

\section{Conclusion}

This comment has attempted to resolve the ambiguity of section 522(d)(5) of the 1978 Bankruptcy Code by examining the historical background, underlying principles, language, legislative history, and practical ramifications of the provision. The better reading of paragraph (5) allows the exemption of only those forms of property specified within section 522(d). Though superficially countertextual and consistently rejected by the courts, this interpretation is in complete accord with the apparent congressional intent.

The most satisfactory resolution of this issue would be for Congress to amend section 522. Given current dissatisfaction with the Code, such a resolution is increasingly likely. ${ }^{138}$ Failing that outcome, however, the courts are still bound to resolve disputes brought before them by using whatever principled basis promises the soundest result. It is hoped that those courts addressing future disputes over paragraph (5) will do so with an eye to the result reached here.

Stephen F. Yunker

declaring a liquidation bankruptcy under chapter 7, 11 U.S.C. $\$ \S 701-766$ (Supp. IV 1980). Because chapter 7 debtors are in most cases able to achieve complete property retention, the incentive to undertake debt repayment under chapter 13 is greatly reduced. This "intrusion" into chapter 13 caused by the Code's exemption scheme, however, may be equally great under either interpretation of paragraph (5) discussed here, given their equivalence in terms of total property value exempted.

${ }^{137}$ See supra notes 35-44 and accompanying text.

${ }^{138}$ See supra note 4. 